\author{
СЕКЦІЯ 3 \\ МІЖКУЛЬТУРНА КОМУНІКАЦІЯ
}

UDC 378.091.313:316.7

DOI https://doi.org/10.32999/ksu2663-3426/2020-2-22

\title{
RECONSIDERING CLIL IN HIGH AND LOW CONTEXT CULTURES
}

\author{
Tkalia Iryna Anatoliivna, \\ Candidate of Philological Sciences, Associate Professor, \\ Associate Professor at the English Language Department \\ V.N. Karazin Kharkiv National University \\ i.a.tkalia@karazin.ua \\ orcid.org/0000-0002-3988-3141 \\ Tsarova Svitlana Oleksiivna, \\ Assistant Professor at the Foreign Languages and Translation Department \\ National Technical University "Kharkiv Polytechnic Institute" \\ s.a.tsaryova@ukr.net \\ orcid.org/0000-0002 8394-1964
}

Purpose. The goal of the research is to analyze psycholinguistic peculiarities of the development of communicative competence and intercultural abilities and skills of university educators and students with reference to high and low context cultures. The emphasis is on the need for introducing cross-cultural aspects to the curricula of Content and Language Integrated Learning (CLIL) courses at tertiary level in Ukraine, especially in the conditions of international academic mobility. Thus, referring to Ukraine as a host country, the relevance of the issue under consideration is determined by the challenge for foreign students to be adapted to Ukraine's socio-cultural conditions and for Ukrainian students to become aware of intercultural values, traditions, and norms of verbal and non-verbal interaction.

Methods. The goal of the research has been achieved through comparative analysis which allows highlighting main dimensions of cultural differences among nationalities including Ukraine, in particular, in low-context and high-context cultures. In the process of achieving this goal we used interdisciplinary approaches as well as the methods of observation and generalization to define intercultural skills and abilities required to gain cross-cultural competence and the methods of induction and systematization to concretize general conclusions.

Results. The existing inseparable relationship of language and culture serves as a key to understanding that language and culture complement each other. It is inevitable to teach foreign culture in a foreign language class. The core of students' cross-cultural competence is to be rooted in cultural sensitivity, i.e. knowledge that there exist cultural differences and similarities among people which can hardly ever be evaluated either positively or negatively. We believe that due to this very factor the ability to overcome stereotypes in intercultural relations can be developed.

Conclusion. Cross-cultural aspects should be included in the curricula of CLIL courses at tertiary level in Ukraine. Hence, classroom activities targeted at building students' competences in "cross-cultural nuances" can be a useful start in preparing students to socialize and perform successfully in their academic and professional endeavors.

Key words: cross-cultural awareness, cross-cultural competence, cross-cultural differences, cultural diversity, intercultural communication, interdisciplinary approaches.

\section{ПРЕДМЕТНО-МОВНЕ IНТЕГРОВАНЕ НАВЧАННЯ В УМОВАХ КУЛЬТУР ВИСОКОГО І НИЗЬКОГО КОНТЕКСТУ}

\author{
Ткаля Ірина Анатоліївна, \\ кандидат фрілологічних наук, доцент, \\ доцент кафедри англійської мови \\ Харківський національний університет імені В.Н. Каразіна \\ i.a.tkalia@karazin.ua \\ orcid.org/0000-0002-3988-3141
}

Царьова Світлана Олексіївна,

доцент кафедри ділової іноземної мови і перекладу

Національний технічний університет «Харківський політехнічний інститут»

s.a.tsaryova@ukr.net

orcid.org/0000-0002 8394-1964 
Мета. Стаття присвячена аналізу особливостей розвитку комунікативної компетенції та міжкультурних здібностей і навичок студентів вищих навчальних закладів в умовах культур високого і низького контексту. Акцент робиться на необхідності впровадження курсів міжкультурної комунікації в навчальні плани на вищому освітньому рівні в Україні згідно із засадами Предметно-мовного інтегрованого навчання (CLIL), зокрема, в умовах міжнародної академічної мобільності. Актуальність цього питання зумовлена необхідністю іноземним студентам, яких приймає Україна, адаптуватися до соціокультурних особливостей та умов навчання в Україні, а українським студентам бути обізнаними щодо цінностей, традицій і норм вербальної та невербальної крос-культурної комунікації.

Memoдu. Mета дослідження досягнута за допомогою порівняльного аналізу, який дає змогу виділити основні аспекти культурних відмінностей між національностями, включаючи Україну, зокрема культурами низького і високого контексту. У процесі досягнення мети використані міждисциплінарні підходи, а також методи спостереження й узагальнення для визначення міжкультурних навичок і здібностей, необхідних для отримання міжкультурної компетенції, а також методи індукції й систематизації для конкретизації загальних висновків.

Результати. Наявні відносини між мовою та культурою слугують ключем до розуміння того, що вони нерозривні й доповнюють один одного. Під час навчання іноземних мов потрібним є навчання особливостей іноземної культури. Ядро міжкультурної компетенції студентів має грунтуватися на культурній чутливості й обізнаності, тобто знаннях того, що існують культурні відмінності й подібності між людьми, які навряд чи коли-небудь можна буде оцінювати позитивно або негативно. Ми вважаємо, що саме завдяки цьому фактору може розвиватися здатність долати стереотипи в міжкультурних відносинах.

Висновки. Міжкультурні аспекти повинні бути включені в навчальні програми курсів Предметно-мовного інтегрованого навчання (CLIL) для вищої освіти в Україні. Отже, заняття в класі, націлені на фрормування в студентів компетенцій у «міжкультурних нюансах», можуть бути корисним початком у підготовці українських та іноземних студентів до здатності спілкуватися з представниками різних культур та успішно виконувати свої навчальні й професійні завдання.

Ключові слова: міжкультурні відмінності, міжкультурна компетенція, міжкультурне спілкування, міждисциплінарні підходи, міжкультурна обізнаність.

\section{Introduction}

Due to dramatic changes in the educational realm, most universities have changed their relevance matrix towards academic mobility where its primary focus is set on developing successful intercultural and professional competences to gain career success worldwide. In particular, much emphasis is made on encouraging students to form awareness of the existing cross-cultural differences since the latter might hinder successful communication with the representatives of the host culture. So the goal of the research is to analyze peculiarities of the development of communicative competence and intercultural abilities and skills of students which will help to be successful in intercultural academic and professional communication. As a result, the immediate need arises for introducing cross-cultural aspects to Ukraine's curricula of Content and Language Integrated Learning (CLIL) courses at tertiary level. Thus, referring to Ukraine as a host country, the relevance of the issue under consideration is determined by the challenge for foreign students to be adapted to Ukraine's socio-cultural conditions. The main objective of the research is to prove that currently, there is an urgent need to teach students cross-cultural differences and to develop their understanding of various verbal and non-verbal communication styles which vary from culture to culture.

2. Theoretical and methodological basis of the research

Communication theorists, anthropologists, psychologists and linguists look at cross-cul- tural communication as a self-governing system of rules which overcomes the communicative barriers set up by national languages (Beamer, 2001; Hall, 1990; Rebrij, 2018). This system largely involves interdisciplinary approaches including world culture studies and psycholinguistics in order to study psychological and neurobiological factors that enable humans to acquire, use, comprehend and produce language (Beattie, Ellis, 2017; Clyne, 1994; Duszak, 1997; Labunets, 2012; Nault, 2006; Nykonenko, 2012).

Interdisciplinary approaches analyze how the transmission of meaning depends not only on the lingual knowledge (grammar, vocabulary, speech practice, etc.) of the speaker and the listener, but also on the context of the utterance, knowledge of the status of those involved, the inferred intent of the speaker, and a number of other discursive factors. These approaches involve psycholinguistics or psychology of language studying the interrelation between linguistic factors and psychological aspects. Moreover, they involve sociolinguistics studying the effects of the context, cultural norms and expectations in the society on the way the language is used and the effects of the language on the society. These approaches also require studying how language varieties differ among groups separated by ethnicity, religion, status, gender, level of education, age.

Besides interdisciplinary approaches, the following theoretical and empirical methods have been applied in the research: observation and generalization methods, and the methods of deduction and systematization to make conclusions. 
Geert Hofstede made one of the most comprehensive analyses of cultural differences among nationalities. He summarized his findings in terms of four dimensions: individualism/collectivism, power distance, uncertainty avoidance, and masculinity/femininity (Hofstede, 1991).

Edward T. Hall and Mildred R. Hall, respected anthropologists and cross-cultural researchers, suggest a system of ways of classifying differences between cultures with reference to the language (Hall, 1990). Their concept of high-context and low-context cultures is of particular significance for the current research. The concept of a low-context culture implies the expression of notions and ideas in written and spoken forms. This type of communication is typically realized by means of the literal language, explicit details, written agreements, etc. Its style will tend to be direct and logical. Japan is the classic example of a high-context culture. The underlying assumption in the culture is that a lot of meaning is carried by the following contextual factors: hierarchy, setting and location. This type of communication is realized through implicit messages, unspoken topics, figurative language, and hints. Its style tends to be indirect and subtle.

Low and high context communication refers not only to individual communication strategies, but may be used to understand cultural groups. According to E. Hall, the USA, Canada, Israel, German-speaking and Scandinavian countries are examples of a low context culture. Generally, Western cultures tend to gravitate toward low context starting points, while Eastern and Southern cultures such as China, Arab countries, Italy, Greece, Japan, Spain, Korean, India, Brazil, and Ukraine tend to use high context communication. Within these huge categories, there are important differences and numerous variations.

Michelle LeBaron stresses that since culture is constantly evolving and changing, people within groups and the contexts around them change (LeBaron, 2003). As people communicate, they move along a continuum between high context and low context. Depending on the kind of relationship, the situation, and the purpose of communication, they may be more or less explicit and direct. There are times when direct, clear communication is the most appropriate, and times when it is preferable to communicate in "layers of meaning" to save face.

Serious communicative failures can occur in interrelations between high context and low context cultures if there is no anticipation of a potential problem. Thus, the representatives of a low context culture may view the representatives of a high context culture as difficult to contact, evasive and vague. On the other hand, the low context people may be viewed as aggressive, impatient, naïve and patronizing. Where high context communication tends to be featured, it is useful to pay specific attention to nonverbal clues and the behavior of others to understand the meaning of what is said. Where low-context communication is the norm, directness is likely to be expected in return.

\section{Development of intercultural awareness of university students}

The subject being discussed sounds particularly relevant when viewed in the context of CLIL courses at the tertiary level in Ukraine. Numerous contemporary research on students' adaptation to a host country outline a wide scope of basic obstacles met in effective cross-cultural communication (Hofstede, 1991; Hall, 1990; LeBaron, 2003; Tokarieva, 2013; Volkova, 2014). Furthermore, cross-cultural communication skills serve to be a prerequisite for understanding the key mental features of the representatives of other cultures which is supposed to foster effective interaction.

Extensive research has resulted in conducting special training aimed at providing tips - both practical and theoretical - to educators working with foreign students (Hofstede, 1991). Genesis of concepts "intercultural communication" and "the language world view" has been researched in linguistic, pedagogical and methodological literature as a means of intercultural communication (LeBaron, 2003). The choice of particular language means may vary considerably depending on the context where numerous factors require maximum flexibly.

In learning and teaching languages it is desirable to identify personal, public, occupational, and educational aspects within social practices. Therefore, it is very much advisable for students to perform communicative tasks related to speech communication in different situations. The tasks may include providing personal information, exchanging information about family, friends, household and other habits, participating in role games, preparing reports for the conference, being involved in interviews with the aim of both obtaining and giving the information. The competences formed might be used as far as they are needed in a variety of contexts, depending on the conditions and requirements of differing types of speech activity. The need and desire to communicate arise in a particular situation, with the form and content of communication as a response to 
the communicative situation (Common European Framework of Reference for Languages: Learning, Teaching, Assessment, 2001: 45).

Knowledge, awareness and understanding of the relation between the "world of origin" and the "world of the target community" coin cross-cultural competence. It should be noted that cross-cultural competence includes the awareness of regional and social diversities in both cultures. It is also enriched by the awareness of a wider range of contexts than those carried by the learners. In addition, cross-cultural competence stems from understanding of how each community appears in the perspective of "the Other", often in the form of national stereotypes (Common European Framework of Reference for Languages: Learning, Teaching, Assessment, 2001: 103). According to the Common European Framework of Reference for Languages, intercultural skills lead to the development of cultural sensitivity, whereby contributing to "the capacity to fulfill the role of cultural intermediary between one's own culture and the foreign culture" and to deal effectively with overcoming cross-cultural misunderstandings and conflict situations (Common European Framework of Reference for Languages: Learning, Teaching, Assessment, 2001: 105). Yet, as the practice shows, the students' communicative potential is influenced not only by their skills and knowledge, but, to a greater extent, by such factors as individual identity, personal values and motivation. Students may have different levels of interest in new knowledge and openness to it. The development of so-called "intercultural identity" which includes both behavior and competence is rightly regarded in many cases as a significant educational goal (Aksyonova, 2012; Токарєва, 2013).

While studying at university, foreign students can realize the existence of different social and cultural aspects of their new environment, such as traditions, values and cultural norms. We consider it essential to emphasize that students learn about intercultural differences and study intercultural communication both through direct communication and in the process of getting acquainted with literary works, mass media, etc. For example, because of respect to the teacher, it is not typical of Chinese students to ask questions in class even if there is something they do not understand. In this case, it is necessary to explain the students that asking teachers in class is very much welcome as a part of an education process. Carefully selected educational texts concerning cultural values and codes of conduct which are typical of a host culture contribute to the expansion of the life experience of learners, and, as a result, to awareness of intercultural differences.

Learning about cultural diversity is also useful for understanding of values, customs, morals and traditions of the student's culture. There is no doubt tha "the more we learn about other cultures, the more we know about our own culture" (Beamer, 2001). When in the classroom we discuss a text associated with national patterns of behavior, students may express their opinion on the issue under consideration, give examples of their own experience, and focus on the aspects related to universal ethics in society. By comparing behavior, traditions and other social and cultural aspects of their and host cultures, foreign students can make their own conclusions as to the differences in living within the scope of diverse fields of the native and new cultural environments. As a result, the audience can understand why people from various cultures behave in this or that way in particular circumstances. They also come to understand the existing differences in their value priorities more effectively.

\section{Conclusions}

The study of intercultural diversity allows us to conclude that cultural differences arise from the historical development of Ukrainian society as mainly collectivist (Hofstede, 1991), although it was influenced by individualistic low-context Western cultures. Now Ukraine is in the evolutionary process of transition from Eurasian identity to its European identity.

Contemporary students represent a new generation, characterized by openness to the outside world. The latter implies that awareness of the differences in norms, values, attitude to what surrounds any person is completely necessary for effective interpersonal and cultural communicative practices. Undoubtedly, culture background and culture impact greatly on adequate language acquisition. Cross-cultural aspects should be included in the curricula of CLIL courses at tertiary level in Ukraine.

In terms of the main goals of CLIL it is appropriate to identify personal, public, occupational, and educational domains. Practice has proved that the communicative potential of students, to a greater extent, is affected by such factors as individual identity, personal values and motivation. We believe that the development of a culturally sensitive personality must be regarded as an important educational goal in CLIL in Ukraine.

Summing up, we hope that this analysis can serve as a basis for the further perspective research into the ways intercultural differences 
manifest themselves in academic and business environment. These findings will act as a foundation for the development of intercultural courses for university students.

\section{BIBLIOGRAPHY:}

1. Аксьонова B.І. Формування комунікативної особистості в умовах глобалізації суспільства. Гуманітарний вісник Запорізької державної інженерної академії. 2012. C. 63-77.

2. Волкова А.Г. Розвиток комунікативної компетенції іноземних студентів в умовах міжкультурного спілкування. Викладання мов у вищих навчальних закладах освіти на сучасному етапі. Серія «Міжпредметні зв'язки» : збірник наукових праць. 2014. Вип. 25. С. 20-27.

3. Лабунець Ю.О. Міжкультурна комунікація як засіб розуміння ментальних особливостей різних культур. Вісник психології та педагогіки : збірник наукових праць / Педагогічний інститут Київського університету імені Бориса Грінченка. 2012. Вип. 7. URL: http://www. psyh.kiev.ua/ (date access: 20.08.2020).

4. Никоненко Я. О. Мовна картина світу як засіб міжкультурної комунікації. Вісник психології та педагогіки : збірник наукових праць. 2012. Вип. 7. URL: http://www. psyh.kiev.ua/ (date access: 20.08.2020).

5. Ребрій О., Ребрій І. Системність і творчість у перекладі: психолінгвістичний підхід. Psycholinguistics. Психолінгвістика. Психолингвистика. Серія «Філологія» : збірник наукових праць. Переяслав-Хмельницький : ФОП Домбровська Я.М. 2018. Вип. 23 (2). С. 180-191.

6. Токарєва А.М. Підготовка студентів до міжкультурної комунікації в контексті фрормування фрахівців-медіаторів культур. Вісник Дніпровського університету імені Альфреда Нобеля. 2013. Вип. 2 (6). С. 48-52.

7. Beamer L., Varner I. International Communication in the Global Workplace. McGraw-Hill Irwin, 2001. 360 p.

8. Beattie G., Ellis A. The psychology of language and communication. Routledge, 2017. 312 p.

9. Clyne M. Inter-cultural Communication at Work: Cultura Values in Discourse. Cambridge University Press, 1994. 260 p.

10. Common European Framework of Reference for Languages: Learning, Teaching, Assessment. Strasbourg: Language Policy Unit, 2001. 261p.

11. Duszak A. Cross-cultural academic communication: a discourse community view. Culture and styles of academic discourse. Berlin : De Gruyter, 1997. P. 11-40.

12. Hall E.T., Hall M.R. Understanding Cultural Differences: Germans, French and Americans. Intercultural Press, 1990. $196 \mathrm{p}$.

13. Hofstede G. Cultures and Organizations: software of the mind. McGraw Hil, 1991. 279 p.

14. LeBaron M. Communication Tools for Understanding Cultural Differences. Beyond Intractability. Conflict Research Consortium. 2003. URL: http://www. beyondintractability.org/essay/communication-tools (date access: 20.08.2020).

15. Nault D. Going Global: Rethinking Culture Teaching in ELT. Contexts. Language, Culture and Curriculum. 2006. № 19 (3). P. 314-328.

\section{REFERENCES:}

1. Aksyonova, V.I. (2012). Formuvannia komunikatyvnoi osobystosti v umovakh hlobalizatsii suspilstva [Formation of communicative personality in the context of globalization of society]. Humanitarnyi visnyk Zaporizkoi derzhavnoi inzhenernoi akademii. Vyp. 49. S. 63-77 [in Ukrainian].

2. Volkova A.G. (2014). Rozvytok komunikatyvnoi kompetentsii inozemnyh studentiv $v$ umovah miszhkul'turnoho spilkuvannia [Foreign students' communication competence development in the framework of intercultural communication]. Mizhpredmetni zv'yazky. Zbirnyk naukovyh prats. Vyp. 25. S. 20-27 [in English].

3. Labunets, Y.O. (2012). Mizhkulturna komunikatsiia yak zasib rozuminnia mentalnykh osoblyvostei riznykh kultur [Intercultural communication as a means of understanding the mental characteristics of different cultures]. Visnyk psykholohii i pedahohiky. Retrieved from: http://www. psyh.kiev.ua/ [in Ukrainian].

4. Nykonenko, Y.O. (2012). Movna kartyna svitu yak zasib mizhkulturnoi komunikatsii [Linguistic picture of the world as a means of intercultural communication]. Visnyk psykholohii i pedahohiky. Retrieved from: http://www. psyh.kiev.ua/ [in Ukrainian].

5. Rebrij, O.V., Rebrij, I.V. (2012). Systemnist' ta tvorchist' u perekladi: psyholinhvistychnyj pidhid [Systematic and creative aspects in translation: the psycholinguistic approach]. II Psycholinhvistyka. : Zbirka naukovyh prats. Seria: Filolohija. Dombrovs'ka. 2018. Vyp. 23(2). S. 180-191 [in Ukrainian].

6. Tokarieva, A.V. (2013). Pidhotovka studentiv do mizhkulturnoi komunikatsii $v$ konteksti formuvannia fakhivtsiv-mediatoriv kultur [Preparation of students for intercultural communication in the context of formation of specialists-mediators of cultures]. Visnyk Dnipropetrovskoho universytetu imeni Alfreda Nobelia. Vyp. 2 (6), 48-52 [in Ukrainian].

7. Beamer L., Varner I. (2001). International Communication in the Global Workplace. McGraw-Hill Irwin. 360 p. [in English].

8. Beattie G., Ellis A. (2017). The psychology of language and communication. Routledge. 312 p. [in English].

9. Clyne, M. (1994). Inter-cultural Communication at Work: Cultural Values in Discourse. Cambridge University Press. 260 p. [in English].

10. Common European Framework of Reference for Languages: Learning, Teaching, Assessment. (2001). Strasbourg: Language Policy Unit. 261 p. [in English].

11. Duszak A. (1997). Cross-cultural academic communication: a discourse community view. Culture and styles of academic discourse. Berlin: De Gruyter. P. 11-40 [in English].

12. Hall E.T., Hall M.R. (1990). Understanding Cultural Differences: Germans, French and Americans. Intercultural Press. 196 p. [in English].

13. Hofstede G. (1991). Cultures and Organizations: software of the mind. McGraw Hill. 279 p. [in English].

14. LeBaron M. (2003). Communication Tools for Understanding Cultural Differences. Beyond Intractability. Conflict Research Consortium. Retrieved from: http:// www.beyondintractability.org/essay/communication-tools.

15. Nault D. (2006). Going Global: Rethinking Culture Teaching in ELT. Contexts. Language, Culture and Curriculum. № 19 (3). P. 314-328.

Стаття надійшла до редакиії 06.10.2020. The article was received October 6, 2020. 